\title{
CHALLENGES OF NEPALESE WOMEN IN PARLIAMENTARY ELECTIONS
}

\author{
Indu Acharya*
}

\begin{abstract}
The country has just passed from the $2^{\text {nd }}$ election for the constituent assembly. Assuring the minimum level of women in the house has been a real challenge; however the recent $C A$ election results have shown a clear decline in the presence of women lawmakers in the house. Despite hard struggle and pressure of women activists and civil society the political parties of the country have failed to keep the level of women's presence in the CA to a level of $33 \%$ as like in the previous CA. In this paper, the researcher has examined the issues and challenges related to women's access to the legislatives in the country in general based on the comparative overview of the last two CA elections from the perspective of women's participation.
\end{abstract}

\section{INTRODUCTION}

Empowerment in general and specifically political empowerment of women is an ongoing struggle of not only in least developed countries and developing countries but also in the developed world. It has been noted, by a research work undertaken recently on 'women's participation in the leadership positions of major political parties of Nepal (Acharya, 2013) that in most of the countries women's political participation is measure and assessed looking into women's participation in the electoral process of the country both at local as well as national level, however the actual source of developing qualified, experienced and strong women candidates takes place within the political parties. If the presence of strong women leaders within the political parties at different levels becomes high, there will be no dearth of strong women candidates to represent the political parties in the elections and win the seat. However, as in many countries of the region, Nepal is not exception to this. This paper intends to discuss the issues and challenges faced by the country in increasing women's presence in the law making bodies, and also by the political parties and individual women politicians aspiring to be in the legislatives in general elections. The last two CA elections and the major political changes in the country after 2006 have raised this issue more significantly ever before.

\section{METHODOLOGY}

This research article is primarily based on the secondary information collected from the previous works of various writers and scholars in the form of

Dr. Acharya is an Associate Professor of Political Science at T.U., Kirtipur, Kathmandu, Nepal. 
books, research papers and general articles published in the newspapers on the issue of women in parliament and also on the topic 'Women in Politics'. Analysis in this article draws from the works and exposure of the writer on the similar topics over the period of last ten years. The results of the CA elections 2008 and 2013 have been taken into considerations and make a significant part of the analysis done in the paper.

ThE SITUATIONAL PORTRAIT OF WOMEN'S PARTICIPATION IN PARLIAMENTS IN NEPAL

The very first parliamentary election took place in Nepal in 1959 but the parliamentary system did not last for more than two years. After the enforcement of Panchayat system in the country the first general election was held in Nepal in 1971, which was based on indirect election system. In 1981 the first direct election for Rastriya Panchayat was held. The 1986 election was the last election in Panchayat System.

After 1990 the first general election for the Parliament under party system was held 1991 followed by 1994, and 1999. In 2008 the first election for Constituent Assembly was held and now the country has recently gone through a fresh election of the Constituent Assembly. During the entire past election events women candidacy and women's participation in the parliament has been always a key issue.

There were only 6 women candidates from different political parties in the first parliamentary elections that took place in Nepal (1959), but all of them lost the election. That parliament lasted only for 18 months as the non party Panchyat system was introduced by the King. During the Panchyat period, under the autocratic regime of the king, people's participation in politics remained as formality and technical only rather than a political process. Only those individuals who opt to accept the 'Panchayat System' were allowed to give their candidacy. Strategically the King and his men would look for cosmetic representation of women, ethnic communities, Dalit and indigenous people while approving candidacy or while nominating members in the Rastriya Panchayat. In the 1981 elections, out of 28 women candidates only 2 women were elected, in the Rastriya Panchayat (RP). In 1986 elections out of 140 total seats only 8 women were elected in the Rastriya Panchayat.

As a result of the compulsory provision in the 1990 constitution that required at least five percent women's candidature in the election for House of Representatives, the number of women candidates in the last three parliamentary elections held in 1991, 1994 and 1999 were gradually increased with a number of 81 (party candidate 73 and 8 independent), 86 (party candidate 74 and 12 independent) and 143 (party candidate 117 and 26 independent) respectively. But out of the total 205 seats only $6(2.9 \%), 7(3.4 \%)$, and $12(5.8 \%)$ women were elected (only party candidates) respectively in 1991, 1994 and 1999 general elections. Dr. Meena Acharya, well known researcher on women issues, after the 
1991 elections, wrote that "In the house of representatives of 205 members, the percentage of women decreased to $3.4 \%$ from what it was in Panchayat period (5.7\%)" (INSEC, 1996).

From the view point of women candidacy and representation in the last CA elections women candidates 2008 and 2013, on the FPTP election held for 240 constituencies there were total 367 in 173 constituencies out of a total of 3947 candidates. In the last CA election 2013 there were total 667 women candidates among a total of 6126 candidates. This makes a $9.3 \%$ women candidate in CA election 2008 and $10.9 \%$ in CA election 2013. This data indicates a slight increase in the number of women taking part in the election process; however it needs to be noted that this increase is more contributed by independent candidates.

As per the election commission data total 30 women candidates won the election under FPTP (12.5\% out of 240), whereas only 12 women came in 2 nd position and 40 in the third position in the 2008 CA election. This situation in CA 2013 has been only 10 women $(4.17 \%$ of 240$)$ candidates winning the election; however 20 women came in the 2nd position and 25 in the third position. The contestants in the 2 nd position increased but it has gone down in the $3^{\text {rd }}$ position. This is an indication that the competitiveness of women candidates still remains on the lower level. There was only one constituency where the winning competition was only between women, and in only two constituencies there were women competitors in 2nd and 3rd position.

In the 2008 CA election $8.17 \%$ of the women candidates were winning candidates in FPTP, whereas this figure has gone down to $1.5 \%$ winning women candidates out of the total women candidates in the CA election held in 2013. This is another indication of decline in the competitiveness of women candidates.

On the Proportional Representation side, because of more political parties entering into election (130 parties in 2013 from 54 parties in 2008) the number of total candidates has gone up by 54.4\% (10709 candidates in 2013 from a 5827 total candidate in 2008). The constitutional provision required to have $50 \%$ women candidate in the PR list for all political parties taking part in the PR election.

In CA election 2008 total 161 women members were elected out of 335 CA members under the Proportionate Representation (PR) system. It was $48.05 \%$ out of $335 \mathrm{CA}$ members. In the latest CA election this scenario came up as 162 women candidate being elected under the PR elections ( $48.36 \% \%$ of 335 seats). The number of women CA members from PR increased by 1 CA member.

In totality, 191 (30 from FPTP and 161 from PR) women were elected as CA members in the 2008 election. This figure stands for $33.2 \%$ of the total 575 CA members. Out of those 26 members nominated by the government only 6 women were included. This way there were 197 (32.78\%) women CA members in the previous CA to fulfill the $33 \%$ bench mark of women representation. In the 
current CA there are only 172 women members coming from both FPTP and PR elections comprising only $30 \%$ of women members in the CA. The nomination of 26 members is yet to take place; until this is done the final number of women members in the CA will not be finalized. It requires 198 women members in the house to make a $33 \%$ presence, but it is unlikely that this is going to be achieved as it will require all 26 nominated members to be women.

The last three national general elections and two CA elections in the country have lead towards few achievements and learning in relation to the participation of women in the parliament. Some new issues and challenges also have emerged out of this learning and achievement process. On the achievement side the interim constitution and related election acts have now assured certain level of women representation on the proportional list, and a minimum level of women candidacy on the direct election side. A large number of women were part of the CA process which has set an example and inspiration to other women up to the grassroots level, which surely increased the confidence level of aspirant women to see themselves in the law making bodies of the country. At least some degree of sensitivity and changed mindset could be presumed in the 'male only' model of political leadership among majority of the political parties towards bringing more women within the political representative bodies of the countries.

Together with achievement and learning scenario, political analysts have also raised the issue of 'quality' of the women CA members in the past CA. The quality issue of the CA members raised only in the case of women members is a bit unfair. The CA member's composition for both men and women was diverse from educational, professional, exposure and involvement point of view. Therefore the 'quality of involvement' issue could equally be raised for men CA members as well.

Most of the political negotiations during the last CA period were largely 'out of parliament' activity and remained concentrated among few high level leaders of limited number of political parties. For other smaller political parties who were not part of this 'out of the parliament negation syndicate' the CA was a place to express their frustration and aspirations only. Therefore the effectiveness and quality of the overall performance of the last CA largely goes to the composition and then political culture practiced by the influential political parties rather than to a group of CA members or individual members. However, the country and its voters would definitely expect the Parliamentarians to deliver quality public goods from the legislature or the CA. The unpleasant failure of the last CA to deliver a 'Constitution' to the country obviously has raised the anger and frustration of the common people. Therefore it is obvious for the common people of this country to be highly skeptical about the performance of this CA also. The ball now is in the court of the Political Parties. It is up to them to prove that they are serious and concerned about the voices and choices of the people of this country, and that they will deliver what the people's are expecting from this CA. 


\section{ISSUES AND CHALLENGES}

On the outset of the starting of this new CA, it will be useful to discuss the key issues and challenges that we have to face regarding women's participation in the political process of this country. Women activists, researchers, political analysts already started raising issues and challenges. Some of the major issues and challenges that need to be addressed to make sure that the political process make enough legitimate space for women citizens of this country.

Based on the experience of last two CA elections it is very clear that there is a need to make clear legislative provisions so that the minimum level of women's participation is assured in all political structures of the country. The political parties complied with the requirements of $50 \%$ women from the PR list, however the lapse was on the FPTP side as there was no clear mandatory level of women candidates to be placed by the political parties. It also seems that a mere provision of $33 \%$ women candidates may not be the solution as the recent CA election results have shown that the men to women competition in the elections of the country do not stand at equal footings.

In addition to this there are other factors that need to be considered in order to increase women's participation in the political process of this country. Inclusion of women voters in the voters list and creating free and safe environment to allow turnover of women voters in the election process remains as a crucial challenge for the country. With growing criminalization of the election process in the country this challenge becomes more and more significant, however with due commitment from the political parties it is not an issue that could not be resolved.

Contesting election to win is a rigorous task for both men and women. Practically women would need more specific and intensive support from their political parties logistically, financially, and physically because their ability to mobilize the party cadre for election campaigning, and logistic mobilization during the election day in the polling booths has its limitations because of the 'male dominated' scenario of election environment. Specific initiatives and vigilants from the senior leadership of the political party will have to be extended if they really want their women candidates to compete and win in the future elections of this country.

Similarly, the women candidates will need a higher level of moral, physical, logistic and financial support from their families and communities. Without significant multi facet support from the family it will be highly difficult for any common women candidate of our society to win the election. The number of high profile national level women leaders who could be strong contentents in the election or in other words 'the winning candidates' are very few. Therefore, if it is regarding to get more number of women winning the CA election, it must be the 'common women'. 
Selecting appropriate and winning women candidate is another major challenge for the political parties. Classically the choice between high profile central level women leaders (belonging to the influence domain and legacy of some dominant male leaders of the party) and the women from the party ranks coming from the local level politics is a real challenge for the political parties. In most of the cases the 'influential' women are chosen as candidates by the party. This is a common case among the developing and developed countries. Nepal is not any exception to this. Many researchers have been questioning whether the presence of 'influential and high profile women' promotes women's political participation in general and contribute to their empowerment or 'women from party ranks' reaching at the higher positions and also taking part in the electoral process from the party contributes for their 'empowerment'.

There are examples from the South Asian region as well as from other parts of the world where there are influential and high level women at top positions but the overall scenario of women's participation inside the political party or in the electoral institutions have not improved. In this context, the references of Bangladesh, Sri Lanka, India are mostly cited by the analysts and researchers as examples of 'influential women reaching at higher political positions of the country but the overall situation of women's participation within the political parties, in the parliaments, and local government institutions not improving'.

The current situation of 'Women's political leadership' of Nepal faces some typical problems such as; i) less numbers of women joining the political parties as members and very few of them reaching to the party leadership role both at local and central level, ii) the domination of 'influential and high profile women' at the leadership role as opposed to the women coming from party rank, and iii) lateral entry in the party from other sectors (civil society, bureaucracy, academia etc.) and representing the party in the national / local electoral process as candidates (Acharya, 2013). Therefore ' who is the right candidate those who have risen from the party cadre and rank or those who come from professional sectors as lateral entry' is a difficult and complex question.

In a context of a different research works related to women's political participation the 'quality' and 'level of contribution' of women CA members from different political parties was raised by the respondents (both men and women political leaders of different parties interviewed by the researcher). There is no doubt that 'the more qualified and experienced members enter in the legislatives the more effective and productive the house could be', however we also need to be realistic and see what is existing on the supply side (among the party cadre and affiliates), and how the equitable presence of women could be assured. For the sake of 'quality' we have not reached to that stage of compromising the 'equitable representation' aspect. 
Most of the political parties across the world are still dominated by male leaders. Most of the political decision making processes among or within the political parties are highly dominated by the male leaders. The recent example of Nepal fits to this context. A lot of high level political negotiations have taken place in Nepal in last ten years or more, however presence of any high-level women leader in such negations was not noticed. The decision on the selection of party candidates for elections are taken in the current male dominated decision making scenario within the political parties, therefore there is always a risk of the candidate selection being bias towards the male leaders of the party. Although the bonding among the women activists is stronger in the civil society, civil rights movement etc., the male bonding within the political parties and groups and subgroups are too strong which often takes decisions isolating the women leaders and members. In this context getting a candidacy becomes a bit cumbersome and complex exercise for the women members. May be because of this situation the political parties are some time criticized as 'old boys club' in many part of the world by women political activists.

\section{CONCLUSION}

As the last $\mathrm{CA}$ election results have shown regression from the previous $\mathrm{CA}$ composition in terms of women's presence in the house, taking actions on the issue of assuring minimum $33 \%$ of Women coming into the legislative bodies of the country in future is becoming more and more urgent concern, especially when the country goes for local elections in near future. Once the country enters into the federal model after the proclamation of the new constitution may be in next two to three years there will be series of new elections at the national, provincial and local level.

Therefore, making statutory provisions in clear term to assure legitimate seats for women in different political structures of the country is essential to assure the desired level of women's representation in the legislative and government bodies. Pursuing the agenda of 'women only constituencies' in the national, provincial and local elections seems to be another aspect of this struggle. Creating avenues to provide support to women candidates for the election from all possible means, and not to penalize only women candidates on the ground of quality is also another area that need to considered.

\section{WORKS CITED}

Acharya, I. (1999). Women's Participation in Local Government. Political Science Association of Nepal, Kathmandu.

--- (2013). Women's participation in leadership role of Major Political Parties of Nepal. Mahila ra Media, Kathmandu: Asmita Women's Publication House.

Baral, L. R., Hachhethu K. and Sharma (2001). Leadership in Nepal: A Pilot Study. New Delhi: Adroit Publishers.

Baral, L. R., Hachhethu K and et al. (2004). Nepal Local Leadership and Governance. New Delhi: Adroit Publishers. 
Bennett, L. (2002). Dangerous Wives and Sacred Sisters. New York: Columbia University Press.

Dhakal, Jibnath \& Hari S. (eds.) (2064 B.S.). Aitihashik Sambidhan Shabha Election. Samchhipta Adhyayan, IIRA-Nepal .

Election Commission (1999). Constituent Assembly Results Booklet. Kathmandu: Election Commission of Nepal.

Insec (1998). Raajnitik Mahila Parichaya. Insec Office, Kathmandu.

Interim Constitution of Nepal (2006). Kanoon Mantralaya, Kathmandu.

Nepalma Mahila ko Rajnitik Sahabhagita Sasktikaran Abam Samabeshikaran. (2065 B.S.). Renaissance Society Nepal.

http://en.wikipedia.org/wiki/Nepalese_Rastriya_Panchayat_election, retrieved on 15 Jan 2014 www.election.gov.np/: election result data retrieved on $15^{\text {th }}$ Jan 2014. 